\title{
Effects of Fertilization and Harvesting Age on Yield and Quality of Desho (Pennisetum pedicellatum) Grass Under Irrigation, in Dehana District, Wag Hemra Zone, Ethiopia
}

\author{
Awoke Kefyalew ${ }^{1}$, Berhanu Alemu², Alemu Tsegaye ${ }^{3}$ \\ ${ }^{1}$ Department of Animal Science, College of Agriculture, Oda Bultum University, Chiro, Ethiopia \\ ${ }^{2}$ Department of Animal Science, College of Agriculture and Natural Resources, Debre Markos University, Debre Markos, Ethiopia \\ ${ }^{3}$ Sekota Dry Land Agricultural Research Center, Sekota, Ethiopia
}

\section{Email address:}

awokekefyalew@gmail.com (A. Kefyalew),berhanualemu@gmail.com (B. Alemu), alemutsg@gmail.com (A. Tsegaye)

\section{To cite this article:}

Awoke Kefyalew, Berhanu Alemu, Alemu Tsegaye. Effects of Fertilization and Harvesting Age on Yield and Quality of Desho (Pennisetum pedicellatum) Grass Under Irrigation, in Dehana District, Wag Hemra Zone, Ethiopia. Agriculture, Forestry and Fisheries.

Vol. 9, No. 4, 2020, pp. 113-121. doi: 10.11648/j.aff.20200904.13

Received: June 5, 2020; Accepted: June 19, 2020; Published: July 28, 2020

\begin{abstract}
The experiment was conducted to evaluating the effects of fertilizer and harvesting age on agronomic performance, chemical composition and economic feasibility of Desho (Pennisetum Pedicellatum) grass under irrigation, in Ethiopia. A factorial arrangement with four fertilizer types (control, urea, compost and urea + compost), and three harvesting ages $(90,120$ and 150) with three replications were used. Data on morphological characteristics of the grass were recorded. Based on the data collected, harvesting age was significantly affected the agronomic parameters of the grass. Plant height (PH), number of tillers per plant (NTPP), number of leaves per plant (NLPP), number of leaves per tiller (NLPT), dry matter yield (DMY), leaf length (LL) and leaf area (LA) were increased with increasing harvesting age, while leaf to stem ratio (LSR) showed a decreasing trend. NDF, ADF and ADL content were also increased with increasing age, while ash declined with age. Fertilizer was also significantly affected the agronomic parameter of Desho grass. A mixture of $50 \mathrm{~kg}$ urea (U)/ha and 6,000 kg compost/ha was provided the highest NTPP, NLPP, NLPT, and DMY, while NF (control) was the lowest in all parameters. Highest NDF, ADF, ADL and ash content were recorded at the control group. In general, using a mixture of $50 \mathrm{~kg}$ urea (U)/ha and 6,000 kg compost/ha fertilizer is the most important for long-term Desho grass production which provides a high benefitcost ratio. Further research is needed in different organic and inorganic fertilizer combinations.
\end{abstract}

Keywords: Compost, Crude Protein, Dry Matter Yield, Harvesting Age, Urea

\section{Introduction}

Ethiopia is believed to have the largest livestock population in Africa [1]. The livestock sector is a significant contributor to Ethiopia's economy at the national and household level [2]. Livestock contributes to the livelihoods of approximately $70 \%$ of Ethiopians and accounts for 15 $17 \%$ of the total national GDP and $35-49 \%$ of the agricultural GDP [2, 3]. Livestock production is an integral part of the subsistence crop-livestock systems in the highlands of Ethiopian, as livestock provide draft power for land preparation and threshing, plus a source of cash income and assets and nutrition for the rural communities [4]. In addition, livestock is considered a mobile bank that can be hired, shared, inherited and contracted by rural households [4].

Despite the significant importance of livestock in the country, the productivity has remained low due to different constraints like inadequate feed, widespread disease, poor health care services, poor genetic potential of indigenous animals and insufficient knowledge on the dynamics of the different farming systems existing in the country [5]. Of these factors, the most limiting one is the feed shortage in terms of quantity and quality [6]. To combat such problems, the use of indigenous forage species as a feed source is mandatory. Among which Desho grass is found to be the most promising one based on the results obtained from preliminary studies [7].

Desho is an indigenous grass of Ethiopia belonging to the 
family Poaceae [8, 9]. It is known as a perennial grass originated in the Southern part of the country. Desho is becoming increasingly popular and can be used for various soil and water conservation practices and as a local method of improving grazing land [10,11], as forage for cattle [12], as an income source by selling the grass splits to other farmers [13], useful for hay and silage making, used in temporary pastures [14]. Desho grass prefers a warm climate and is found in regions of rainfall ranging from 800 to 1250 $\mathrm{mm}$ [15]. It responds well to fertilizer and can be combined with fodder legumes, either in mixtures or in rotation cropping system [16].

Even though Desho grass has such numerous importance as somewhere in the text, information on the effect of fertilizer type, harvesting age and their interaction on agronomic performance is limited. In this regard [7] suggested trails to be conducted on fertilizer types and levels to investigate the response of this grass to recommend the optimum production package. Therefore; the current study was designed with the objective of evaluating the agronomic performance, chemical composition and economic feasibility of Desho grass using different harvesting ages and fertilizer level and types.

\section{Materials and Methods}

\subsection{Description of the Study Area}

The study was conducted in Dehana district by the side of (Gibz river) basin found in Wag Hemra Zone, Amhara National Regional State. The area is situated at a geographical location of $12^{\circ} 10^{\prime}$ and $12^{\circ} 39^{\prime}$ 'North latitudes and $38^{\circ} 25^{\prime}$ and $39^{\circ} 00^{\prime}$ East longitudes. The district is bordered in the south by North Wollo Zone, in the west by the Tekezé River which separates it from South Gondar Zone and in the north by North Gondar Zone and Zikuala, in the northeast by Soqota, and in the east by Gazgibla district. Amdework which is the administrative center of Dehana is found $78 \mathrm{~km}$ from Sekota (the center of Wag Hemra Administrative Zone); $520 \mathrm{~km}$ northeast of Bahir Dar, the capital of the region and $798 \mathrm{~km}$ north of Addis Ababa, the capital of the country. The altitudinal range of the district is from 1205 to $3138 \mathrm{~m}$. a. s. 1 . The range of annual rainfall of the area is mostly between $700-800 \mathrm{~mm}$, with the main rainy month being mainly from June to September with the pattern and distribution being erratic and uneven. The minimum and maximum temperatures of the area are 12 and $37^{\circ} \mathrm{C}$, respectively.

\subsection{Treatments and Experimental Design}

The experiment was conducted using a $3 \times 4$ factorial arrangements in a Randomized Complete Block Design (RCBD). The first factor was harvesting age with three harvesting days, (1). 90 days, (2). 120 days, and (3). 150 days after planting. The second factor was fertilizer level and type (compost and urea) with four combinations comprising of: FL1 (control) without fertilizer, FL2 (12,000 kg compost/ha, FL3 (100 kg urea (U)/ha) and FL4 (a mixture of $50 \mathrm{~kg}$ urea and $6,000 \mathrm{~kg}$ compost/ha. The experiment had 12 treatment combinations having three replications and a total of 36 plots (Table 1). The experimental field had a total area of 29.5 $\mathrm{m} \times 11 \mathrm{~m}\left(324.5 \mathrm{~m}^{2}\right)$ with the plot size being $3 \mathrm{~m}$ width $\times 2 \mathrm{~m}$ length $=\left(6 \mathrm{~m}^{2}\right)$. The space between blocks and plots were 1 $\mathrm{m}$ and $0.5 \mathrm{~m}$, respectively. The spacing between plants and rows were $50 \mathrm{~cm}$ and $75 \mathrm{~cm}$, respectively.

Table 1. Experimental treatment combinations.

\begin{tabular}{llll}
\hline \multirow{3}{*}{ fertilizer types and levels } & \multicolumn{3}{l}{ Treatment combination } \\
\cline { 2 - 4 } & Harvesting ages & HA2 & HA3 \\
\cline { 2 - 4 } & HA1 & FL1 $\times$ HA2 (T2) & FL1 $\times$ HA3 (T3) \\
\hline FL1 & FL2 $\times$ HA1 $($ T1) & FL2 $\times$ HA2 (T5) & FL2 $\times$ HA3 (T6) \\
FL2 & FL3 $\times$ HA1 (T7) & FL3 $\times$ HA2 (T8) & FL3 $\times$ HA3 (T9) \\
FL3 & FL4 $\times$ HA1 (T10) & FL4 $\times$ HA2 (T11) & FL4 $\times$ HA3 (T12) \\
\hline
\end{tabular}

$\mathrm{FL}=$ fertilizer level; FL1=control; FL2=12,000 kg/ha compost; FL3=100kg U/ha; FL4=a mixture of $50 \mathrm{~kg}$ Urea $* 6,000 \mathrm{~kg}$ compost/ha; HA= harvesting Age; $\mathrm{HA} 1=90$ days after planting; $\mathrm{HA} 2=120$ days after planting; $\mathrm{HA} 3=150$ days after planting; $\mathrm{T} 1-\mathrm{T} 12=$ treatment one to treatment 12

\subsection{Preparation of Land and Experimental Material}

The experimental site was ploughed and harrowed during August and September. A total of Nine hundred similar root splits of Desho grass with good vigor, strength, and freedom from injury were taken from Debre Markos university grass nursery site and transported to Dehana district. Urea and compost were obtained from local rural kebeles of Dehana district. A total of $97.2 \mathrm{~kg}$ compost and $0.81 \mathrm{~kg}$ urea were used for the total experiment. The experiment was started in September and completed in February under irrigation condition. Before uprooting the seedlings, the leaves were removed to reduce wilting by more water loss through transpiration, which can cause death of plants during transportation.

\subsection{Establishment and Management Practices}

Weeds were removed manually during the experimental period. Water was applied three times a week for the first month and one times a week afterwards. Each block and plot were irrigated separately. Urea, compost and their mixture were applied based on the treatments set to each plot. Compost was applied before planting and urea was applied in split, half at planting and the rest half after the $70^{\text {th }}$ day of age when the plants developed a well-established root system. The harvesting ages one, two and three abbreviated as HA1, HA 2 and HA3 were done at the $90^{\text {th }}, 120^{\text {th }}$ and $150^{\text {th }}$ day after 
planting, respectively. Harvesting was done by hand using a sickle, at a height of about $5 \mathrm{~cm}$ from ground level [17].

\subsection{Data Collection and Sampling Procedures}

Data on agronomic parameters were recorded every 20 days starting from the $50^{\text {th }}$ day of age. Plant height was measured from ground level to the tip of the longest leaf. Number of tillers per plant, number of leaves per plant and number of leaves per tiller were recorded from average of ten randomly selected plants from the middle rows of each plot [17]. Leaf area was calculated by multiplying leaf length by the average leaf width taken from bottom, mid and tip of the leaf. Leaf length was measured from the bottom to the tip of the leaf. Leaf to stem ratio was determined from each plot by separating leaf and stem portions and weighing the leaf and the stem separately then dividing the leaf weight by the stem weight. The total biomass yield was determined by harvesting the three middle rows from each plot at each harvesting age leaving border rows. The fresh biomass yield was determined right after harvesting using field balance.
Subsample of each treatment $(0.5 \mathrm{~kg})$ was taken, air dried and then oven dried at $105^{\circ} \mathrm{C}$ for 24 hours to determine the total dry matter yield/unit area and a portion of these samples were used for chemical analysis purposes.

\subsection{Forage Sample Collection, Preparation and Analysis}

Dried forage samples were grounded to pass through a 1 $\mathrm{mm}$ sieve screen (Willy mill) for analysis of chemical composition. The ground samples were stored in an airtight plastic bag pending chemical analysis. Determination of DM, $\mathrm{CP}$ and total ash contents were carried out using procedures described by [18]. Laboratory procedure were followed to determine the NDF, ADF and ADL contents of the grass (19).

\subsection{Economic Analysis}

Economic analysis was done to know the most economically feasible fertilizer types by using the following formula:

\section{Total expenditure $=$ Total fixed cost + Total variable cost}

$$
\begin{gathered}
\text { Net income }=\text { Gross income }- \text { Total expenditure } \\
\text { Benefit cost ratio }=\frac{\text { Gross income }}{\text { Total expenditure }}
\end{gathered}
$$

Where: Total fixed cost $=$ costs expended from planting to the end of the research

Total variable cost $=$ costs of fertilizer

Gross income $=$ incomes from the sale of the grass

\subsection{Statistical Analysis}

The data collected were subjected to analysis of variance (ANOVA) using SAS software [20]. The mean of the treatments was compared using Duncan's Multiple Range Test (DMRT). The effect of different fertilizer, harvesting age and their interaction on morphological characteristics, yield and chemical composition were determined using the following model;

$$
\mathrm{Y}_{\mathrm{ijk}}=\mu+\mathrm{B}_{\mathrm{i}}+\mathrm{F}_{\mathrm{j}}+\mathrm{H}_{\mathrm{k}}+(\mathrm{FH})_{\mathrm{jk}}+\varepsilon_{\mathrm{ijk}}
$$

Where:

$\mathrm{y}_{\mathrm{ijk}}=$ the response variables

$\mu=$ overall mean

$\mathrm{Bi}=$ Effects of $\mathrm{i}^{\text {th }}$ block

$F_{j}=$ Effect of $j^{\text {th }}$ fertilizer

$\mathrm{H}_{\mathrm{k}}=$ Effects of $\mathrm{k}^{\text {th }}$ harvesting days

$\mathrm{FH}_{\mathrm{jk}}=$ Interaction between fertilizer and harvesting days

$\varepsilon_{\mathrm{ijk}}=$ random error

\section{Results}

\subsection{Morphological Parameter of Desho (pennistum Pedicellatum) Grass}

\subsubsection{Plant Height, Leaf Length, Leaf Area and Leaf to Stem Ratio}

The effect of harvesting age and fertilizer type on plant height, leaf length, leaf area, and leaf to stem ratios are indicated in Table 2. In the current study, plant height, leaf length, leaf area, and leaf to stem ratios were significantly $(p<0.01)$ affected by harvesting age and fertilizer level, but not by their interaction. Plant height increased from a lower level $37.19 \mathrm{~cm}$ at 90 days of age to a significantly higher value $45.43 \mathrm{~cm}$ at the age of 150 days. Leaf length and leaf area were also increased from $20.91 \mathrm{~cm}$ to $23.38 \mathrm{~cm}$ and $20.33 \mathrm{~cm}^{2}$ to $23.29 \mathrm{~cm}^{2}$, respectively as harvesting age increased from 90 days to 150 days of age, while leaf to stem ratios declined from 1.76 to 0.79 as age of plants advanced.

Application of fertilizer levels (FL1-FL3) gave the highest but statistically similar plant height and leaf area values over the control treatment (FL1). Significantly higher but statistically similar values of leaf length $(24.19 \mathrm{~cm})$ and $(23.51 \mathrm{~cm})$ were recorded for FL3 and FL4, respectively. On the other hand, the highest but statistically similar values of leaf to stem ratios 1.26 and 1.20 were recorded for FL1 and

\begin{tabular}{|c|c|c|c|c|c|c|c|c|c|}
\hline \multirow{2}{*}{ Parameter } & \multicolumn{4}{|c|}{ Harvesting age (HA) } & \multicolumn{5}{|c|}{ Fertilizer type and level (FL) } \\
\hline & HA1 & HA2 & HA3 & Mean & FL1 & FL2 & FL3 & FL4 & Mean \\
\hline Plant height $(\mathrm{PH})(\mathrm{cm})$ & $37.19^{\mathrm{c}}$ & $40.48^{\mathrm{b}}$ & $45.43^{\mathrm{a}}$ & 41.03 & $37.48^{b}$ & $40.80^{\mathrm{a}}$ & $42.15^{\mathrm{a}}$ & $42.99^{\mathrm{a}}$ & 40.86 \\
\hline Leaf length (LL) & $20.91^{\mathrm{b}}$ & $23.37^{\mathrm{a}}$ & $23.38^{\mathrm{a}}$ & 22.55 & $20.38^{\mathrm{c}}$ & $22.13^{\mathrm{b}}$ & $24.19^{\mathrm{a}}$ & $23.51^{\mathrm{ab}}$ & 22.55 \\
\hline
\end{tabular}
FL2, respectively.

Table 2. Mean plant height, leaf length, leaf area and leaf to stem ratios as affected by harvesting age and fertilization. 


\begin{tabular}{|c|c|c|c|c|c|c|c|c|c|}
\hline \multirow{2}{*}{ Parameter } & \multicolumn{4}{|c|}{ Harvesting age (HA) } & \multicolumn{5}{|c|}{ Fertilizer type and level (FL) } \\
\hline & HA1 & HA2 & HA3 & Mean & FL1 & FL2 & FL3 & FL4 & Mean \\
\hline Leaf area (LA) & $20.33^{b}$ & $23.49^{\mathrm{a}}$ & $23.29^{\mathrm{a}}$ & 22.37 & $19.31^{b}$ & $21.95^{\mathrm{a}}$ & $24.25^{\mathrm{a}}$ & $23.98^{\mathrm{a}}$ & 22.37 \\
\hline \multirow[t]{2}{*}{ Leaf to stem ratio (LSR) } & $1.76^{\mathrm{a}}$ & $0.87^{\mathrm{b}}$ & $0.79^{\mathrm{c}}$ & 1.14 & $1.26^{\mathrm{a}}$ & $1.20^{\mathrm{a}}$ & $1.06^{\mathrm{b}}$ & $1.03^{\mathrm{b}}$ & 1.14 \\
\hline & $\mathrm{PH}$ & LL & LA & LSR & & & & & \\
\hline $\mathrm{CV}$ & 7.23 & 6.92 & 10.68 & 8.21 & & & & & \\
\hline SEM & 2.97 & 1.56 & 2.39 & 0.09 & & & & & \\
\hline P-Value & $\begin{array}{l}\text { HA } \\
<0.01\end{array}$ & $\begin{array}{l}\text { FL } \\
<0.01\end{array}$ & $\begin{array}{l}\text { Interac } \\
>0.05\end{array}$ & & & & & & \\
\hline
\end{tabular}

Means with different superscripts in a column and rows are significantly different from each other at $\mathrm{p}<0.05 ; \mathrm{FL}=$ fertilizer level; FL1 $=$ control; FL2 $=12,000$ $\mathrm{kg} / \mathrm{ha}$ compost; FL3 $=100 \mathrm{~kg} \mathrm{U} / \mathrm{ha}$; FL4=a mixture of $50 \mathrm{~kg} \mathrm{Urea} * 6,000 \mathrm{~kg}$ compost $/ \mathrm{ha} ; \mathrm{HA}=$ harvesting Age; HA1= 90 days after planting; HA2=120 days after planting; $\mathrm{HA} 3=150$ days after planting; $\mathrm{CV}=$ coefficient of variation; $\mathrm{SEM}=$ standard error of mean

\subsubsection{Number of Tiller Per Plant and Number of Leaves Per Plant}

The effect of fertilizer type, harvesting age and their interaction on number of tiller and number of leaves per plant is indicated in Table 3. In this case, tiller number and number of leaves per plant were significantly $(\mathrm{p}<0.01)$ affected by fertilizer type, harvesting age and their interactions. Significantly higher tillers per plant and leaves per plant were recorded for FL4HA3 (102.95 tillers) and (770.50 leaves), respectively. Generally, tiller and leaf numbers were found to be lower for FL1 at all harvesting ages.
The highest tillers per plant (79.84) and leave number per plant (593.47) were recorded at late harvesting age (150 days), while the least tiller number (42.23) and leaves (212.09) were counted at early harvesting age (90 days). Number of tiller and leaves per plant were also affected $(p<0.001)$ by fertilizer application in which the highest tiller/plant (78.39) and leaves (530.08) were recorded at a fertilizer level of FL4 $(50 \mathrm{~kg} \mathrm{U} / \mathrm{ha} \times 6,000 \mathrm{~kg} \mathrm{C} / \mathrm{ha})$, while the lowest tillers/plant (45.05) and leaves/plant (306.36) were counted from FL1 (no fertilizer).

Table 3. Mean tiller number/plant and number of leaves/plants as affected by harvesting age and fertilizer.

\begin{tabular}{|c|c|c|c|c|c|c|c|c|}
\hline \multirow{3}{*}{$\begin{array}{l}\text { Fertilizer types } \\
\text { \& levels (FL) }\end{array}$} & \multicolumn{4}{|c|}{ Number of tillers per plant } & \multicolumn{4}{|c|}{ Number of leaves per plant } \\
\hline & \multicolumn{4}{|c|}{ Harvesting age (HA) } & \multicolumn{4}{|c|}{ Harvesting age } \\
\hline & HA1 & HA2 & HA3 & Mean & HA1 & HA2 & HA3 & Mean \\
\hline FL1 & $38.50^{\mathrm{e}}$ & $44.60^{\mathrm{e}}$ & $52.06^{\mathrm{e}}$ & $45.05^{x}$ & $187.77^{\mathrm{e}}$ & $300.90^{\mathrm{e}}$ & $430.40^{\mathrm{d}}$ & $306.36^{x}$ \\
\hline FL2 & $41.80^{\mathrm{e}}$ & $68.13^{\mathrm{d}}$ & $74.70^{\mathrm{cd}}$ & $61.54^{\mathrm{w}}$ & $203.10^{\text {ef }}$ & $476.47^{\mathrm{d}}$ & $522.90^{\mathrm{cd}}$ & $400.82^{w}$ \\
\hline FL3 & $44.67^{\mathrm{e}}$ & $74.55^{\mathrm{cd}}$ & $89.67^{b}$ & $69.62^{v}$ & $233.51^{\mathrm{ef}}$ & $515.80^{\text {cd }}$ & $650.08^{\mathrm{b}}$ & $466.46^{\mathrm{v}}$ \\
\hline FL4 & $43.93^{\mathrm{e}}$ & $88.30^{\mathrm{bc}}$ & $102.95^{\mathrm{a}}$ & $78.39^{\mathrm{u}}$ & $224.00^{\text {ef }}$ & $595.75^{\mathrm{bc}}$ & $770.50^{\mathrm{a}}$ & $530.08^{u}$ \\
\hline Mean & $42.23^{z}$ & $68.90^{\mathrm{y}}$ & $79.84^{x}$ & 64.05 & $212.09^{z}$ & $472.23^{y}$ & $593.47^{x}$ & 425.93 \\
\hline $\mathrm{CV}$ & 12.8 & & & & 12.7 & & & \\
\hline SEM & 7.75 & & & & 54.11 & & & \\
\hline P-value & HA & FL & Interaction & & HA & FL & Interaction & \\
\hline P-value & $<0.001$ & $<0.001$ & $<0.001$ & & $<0.001$ & $<0.001$ & $<0.001$ & \\
\hline
\end{tabular}

Means with different superscripts in a column and rows are significantly different from each other at $\mathrm{p}<0.05 ; \mathrm{FL}=$ fertilizer level; FL1 $=$ control; FL2 $=12,000$ $\mathrm{kg} / \mathrm{ha}$ compost; FL3 $=100 \mathrm{~kg} \mathrm{U} / \mathrm{ha}$; FL4=a mixture of $50 \mathrm{~kg}$ Urea $* 6,000 \mathrm{~kg}$ compost $/ \mathrm{ha} ; \mathrm{HA}=$ harvesting Age; HA1= 90 days after planting; HA2=120 days after planting; $\mathrm{HA} 3=150$ days after planting; $\mathrm{CV}=$ coefficient of variation; $\mathrm{SEM}=$ standard error of mean

\subsubsection{Number of Leaves Per Tiller and Dry Matter Yield}

Number of leaves per tiller and dry matter yield were significantly $(p<0.001)$ affected by harvesting age, fertilizer level and their interactions (Table 4). For the interaction effects, significantly higher leaf numbers/tiller were recorded for FL4HA3 (9.25) followed by FL2HA3 (8.35) and FL3HA3 (8.17).

Generally, leaf numbers per tiller were found to be lower for FL1HA1 (5.30). On the other hand, the highest dry matter yield $(11.38 \mathrm{t} / \mathrm{ha})$ was recorded for FL4HA3 followed by
FL3HA3 (8.99 t/ha), while the least but statistically similar values were recorded for HA1 at all fertilizer levels.

Harvesting at the age of 150 days gave the highest number of leaves per tiller (8.40) and dry matter yield ( $7.88 \mathrm{t} / \mathrm{ha})$ compared to harvesting at 90 and 120 days of age. Fertilizer also significant affected $(\mathrm{p}<0.001)$ number of leaves/tiller and dry matter yield in which the highest leaf number per tiller (7.75) and dry matter yield (5.54 t/ha) were recorded at a fertilizer level of $50 \mathrm{~kg} \mathrm{U} \mathrm{X}$ 6,000 compost/ha, whereas the least 6.52 leaves/tiller and 2.33 tha were obtained at FL1 (without fertilizer).

Table 4. Mean number of leaves per tiller and dry matter yield/ha as affected by harvesting age and fertilizer type.

\begin{tabular}{|c|c|c|c|c|c|c|c|c|}
\hline \multirow{3}{*}{$\begin{array}{l}\text { Fertilizer types \& } \\
\text { Levels (FL) }\end{array}$} & \multicolumn{4}{|c|}{ Number of leaves/tillers } & \multicolumn{4}{|c|}{ Dry matter yield/ha } \\
\hline & \multicolumn{4}{|c|}{ Harvesting age (HA) } & \multicolumn{4}{|c|}{ Harvesting age (HA) } \\
\hline & HA1 & HA2 & HA3 & Mean & HA1 & HA2 & HA3 & Mean \\
\hline FL1 & $5.30^{\mathrm{h}}$ & $6.45^{\mathrm{fg}}$ & $7.82^{\mathrm{d}}$ & $6.52^{\mathrm{c}}$ & $1.03^{\mathrm{f}}$ & $2.18^{\mathrm{e}}$ & $3.77^{\mathrm{d}}$ & $2.33^{\mathrm{d}}$ \\
\hline FL2 & $6.49^{f}$ & $6.97^{\mathrm{e}}$ & $8.35^{\mathrm{b}}$ & $7.27^{\mathrm{b}}$ & $1.21^{\mathrm{f}}$ & $3.31^{\mathrm{d}}$ & $7.36^{\mathrm{c}}$ & $3.96^{\mathrm{c}}$ \\
\hline FL3 & $6.90^{\mathrm{e}}$ & $7.13^{\mathrm{e}}$ & $8.17^{\mathrm{bc}}$ & $7.40^{\mathrm{b}}$ & $1.33^{\mathrm{f}}$ & $3.52^{\mathrm{d}}$ & $8.99^{\mathrm{b}}$ & $4.62^{\mathrm{b}}$ \\
\hline
\end{tabular}




\begin{tabular}{|c|c|c|c|c|c|c|c|c|}
\hline \multirow{3}{*}{$\begin{array}{l}\text { Fertilizer types \& } \\
\text { Levels (FL) }\end{array}$} & \multicolumn{4}{|c|}{ Number of leaves/tillers } & \multicolumn{4}{|c|}{ Dry matter yield/ha } \\
\hline & \multicolumn{4}{|c|}{ Harvesting age (HA) } & \multicolumn{4}{|c|}{ Harvesting age (HA) } \\
\hline & HA1 & HA2 & HA3 & Mean & HA1 & HA2 & HA3 & Mean \\
\hline FL4 & $6.15^{\mathrm{g}}$ & $7.85^{\mathrm{cd}}$ & $9.25^{\mathrm{a}}$ & $7.75^{\mathrm{a}}$ & $1.28^{\mathrm{f}}$ & $3.95^{\mathrm{d}}$ & $11.38^{\mathrm{a}}$ & $5.54^{\mathrm{a}}$ \\
\hline Mean & $6.21^{\mathrm{c}}$ & $7.10^{\mathrm{b}}$ & $8.40^{\mathrm{a}}$ & 7.24 & $1.21^{\mathrm{z}}$ & $3.24^{\mathrm{y}}$ & $7.88^{x}$ & 4.11 \\
\hline $\mathrm{CV}$ & 2.6 & & & & 10.02 & & & \\
\hline SEM & 0.19 & & & & 0.41 & & & \\
\hline D & HA & FL & Interaction & & HA & FL & Interaction & \\
\hline P-value & $<0.001$ & $<0.001$ & $<0.001$ & & $<0.001$ & $<0.001$ & $<0.001$ & \\
\hline
\end{tabular}

Means with different superscripts in a column and rows are significantly different from each other at $\mathrm{p}<0.05 ; \mathrm{FL}=$ fertilizer level; FL1=control; FL2=12,000 $\mathrm{kg} / \mathrm{ha}$ compost; FL3=100kg U/ha; FL4=a mixture of $50 \mathrm{~kg}$ Urea $* 6,000 \mathrm{~kg}$ compost $/ \mathrm{ha} ; \mathrm{HA}=$ harvesting Age; HA1= 90 days after planting; HA2=120 days after planting; $\mathrm{HA} 3=150$ days after planting; $\mathrm{CV}=$ coefficient of variation; $\mathrm{SEM}=$ standard error of mean

\subsection{Chemical Composition of Desho (pennisteum pedicellatum) Grass}

\subsubsection{DM\%, NDF, ADF, ADL and ash}

The effects of fertilizer and harvesting age on $\mathrm{DM} \%, \mathrm{CP} \%$, NDF, ADF, ADL and ash content of Desho grass is shown in Table 5. The effect of harvesting age was significantly affected $\mathrm{DM} \%, \mathrm{CP} \%$, NDF, ADF, ADL and ash content, while interaction effect was showed non-significant effect $(\mathrm{p}>0.05) . \mathrm{DM} \%$, NDF, ADF and ADL increases with increasing harvesting age, while $\mathrm{CP} \%$ and ash content showed decreasing trends. The effects of fertilizer on DM\% showed non-significant difference, while $\mathrm{CP} \%$, NDF, ADF, ADL and ash content were significantly affected by fertilizer types. Highest $\mathrm{CP} \%$ was obtained from $100 \mathrm{~kg}$ urea fertilizer plot, in the other hand highest NDF, ADF, ADL and ash were recorded at the control groups.

Table 5. DM\%, NDF, ADF, ADL and ash as affected by harvesting age and fertilizer type.

\begin{tabular}{|c|c|c|c|c|c|c|c|c|c|}
\hline \multirow{2}{*}{ Parameter } & \multicolumn{4}{|c|}{ Harvesting age } & \multicolumn{5}{|c|}{ Fertilizer type and level } \\
\hline & HA1 & HA2 & HA3 & Mean & FL1 & FL2 & FL3 & FL4 & Mean \\
\hline DM\% & $94.25^{b}$ & $94.25^{\mathrm{b}}$ & $95.25^{\mathrm{a}}$ & 94.58 & 94.22 & 95.00 & 94.56 & 94.56 & 94.58 \\
\hline $\mathrm{CP} \%$ & $13.78^{\mathrm{a}}$ & $9.23^{\mathrm{b}}$ & $7.58^{\mathrm{c}}$ & 10.20 & $8.74^{\mathrm{c}}$ & $9.90^{\mathrm{b}}$ & $11.70^{\mathrm{a}}$ & $10.47^{\mathrm{b}}$ & 10.20 \\
\hline NDF & $55.76^{\mathrm{c}}$ & $57.52^{\mathrm{b}}$ & $59.74^{\mathrm{a}}$ & 57.67 & $59.41^{\mathrm{a}}$ & $57.97^{\mathrm{b}}$ & $56.09^{c}$ & $57.21^{\mathrm{bc}}$ & 57.67 \\
\hline $\mathrm{ADF}$ & $43.16^{\mathrm{c}}$ & $45.17^{\mathrm{b}}$ & $46.72^{\mathrm{a}}$ & 45.01 & $46.85^{\mathrm{a}}$ & $45.47^{\mathrm{b}}$ & $42.70^{\mathrm{c}}$ & $45.01^{\mathrm{b}}$ & 45.01 \\
\hline $\mathrm{ADL}$ & $11.34^{\mathrm{c}}$ & $12.11^{\mathrm{b}}$ & $13.20^{\mathrm{a}}$ & 12.22 & $13.08^{\mathrm{a}}$ & $12.30^{\mathrm{b}}$ & $11.25^{\mathrm{c}}$ & $12.24^{\mathrm{b}}$ & 12.22 \\
\hline \multirow[t]{2}{*}{ Ash } & $15.77^{\mathrm{a}}$ & $14.41^{\mathrm{b}}$ & $13.56^{\mathrm{c}}$ & 14.58 & $15.56^{\mathrm{a}}$ & $15.24^{\mathrm{a}}$ & $13.53^{\mathrm{b}}$ & $13.99^{\mathrm{b}}$ & 14.58 \\
\hline & DM\% & $\mathrm{CP} \%$ & NDF & ADF & ADL & Ash & & & \\
\hline $\mathrm{CV}$ & 0.75 & 8.77 & 2.48 & 2.99 & 3.92 & & 5.83 & & \\
\hline SEM & 0.71 & 0.89 & 1.43 & 1.34 & 0.48 & & 0.85 & & \\
\hline \multicolumn{5}{|c|}{$\mathrm{CP} \%$, NDF, ADF, ADL and Ash } & \multicolumn{5}{|l|}{ DM\% } \\
\hline P-value & $\begin{array}{l}\text { HA } \\
<0.01\end{array}$ & $\begin{array}{l}\text { FL } \\
<0,01\end{array}$ & $\begin{array}{l}\text { Interaction } \\
>0.05\end{array}$ & & $\begin{array}{l}\text { HA } \\
>005\end{array}$ & & $\begin{array}{l}\text { FL } \\
<0,01\end{array}$ & Interact & \\
\hline
\end{tabular}

Means with different superscripts in a column and rows are significantly different from each other at $\mathrm{p}<0.05 ; \mathrm{FL}=$ fertilizer level; FL1=control; FL2=12,000 $\mathrm{kg} / \mathrm{ha}$ compost; FL3 $=100 \mathrm{~kg} \mathrm{U} / \mathrm{ha} ; \mathrm{FL} 4=\mathrm{a}$ mixture of $50 \mathrm{~kg}$ Urea $* 6,000 \mathrm{~kg}$ compost $/ \mathrm{ha} ; \mathrm{HA}=$ harvesting Age; HA1= 90 days after planting; HA2=120 days after planting; $\mathrm{HA} 3=150$ days after planting; $\mathrm{CV}=$ coefficient of variation; $\mathrm{SEM}=$ standard error of mean; $\mathrm{DM} \%=\mathrm{Dry}$ Matter percentage; $\mathrm{CP} \%=\mathrm{Crude}$ Protein percentage; $\mathrm{NDF}=$ Neutral Detergent Fiber; $\mathrm{ADF}=$ Acid Detergent Fiber; ADL $=$ Acid Detergent Lignin, $\mathrm{C} \mathrm{CV}=$ coefficient of variation; $\mathrm{SEM}=$ standard error of mean.

\subsubsection{Crude Protein}

As indicated in Table 6, the effect of harvesting age and fertilizer was significantly affected crude protein percentage, while the interaction between the two factors had nonsignificant effect $(\mathrm{p}>0.05)$. Highest $\mathrm{CP}$ was obtained at the first harvesting age (13.78); On the other hand, lowest $\mathrm{CP}$ was obtained at late harvesting age (7.58). This shows that $\mathrm{CP}$ declines as harvesting age advanced.

The CP content of $100 \mathrm{~kg} \mathrm{U} / \mathrm{ha}$ (11.70) was significantly higher $(\mathrm{p}<0.001)$ than the other fertilizers, while NF (control) was provided the lowest $\mathrm{CP}$ content (8.74) (Table 6).

Table 6. Crude protein as affected by fertilizer type and harvesting age.

\begin{tabular}{lllll}
\hline \multirow{2}{*}{$\begin{array}{l}\text { Fertilizer types } \\
\text { and levels }\end{array}$} & \multicolumn{4}{l}{ Harvesting age } \\
\cline { 2 - 5 } & HA1 & HA2 & HA3 & Mean \\
\hline FL1 & 10.86 & 8.62 & 6.73 & $8.74^{\mathrm{c}}$ \\
FL2 & 13.57 & 8.99 & 7.11 & $9.89^{\mathrm{b}}$ \\
\hline
\end{tabular}

\begin{tabular}{lllll}
\hline \multirow{2}{*}{$\begin{array}{l}\text { Fertilizer types } \\
\text { and levels }\end{array}$} & \multicolumn{4}{l}{ Harvesting age } \\
\cline { 2 - 5 } & HA1 & HA2 & HA3 & Mean \\
\hline FL3 & 16.78 & 9.78 & 8.54 & $11.70^{\mathrm{a}}$ \\
FL4 & 13.92 & 9.56 & 7.93 & $10.47^{\mathrm{b}}$ \\
Mean & $13.78^{\mathrm{a}}$ & $9.23^{\mathrm{b}}$ & $7.58^{\mathrm{c}}$ & 10.20 \\
CV & 8.77 & & & \\
SE & 0.89 & & \\
\hline \multicolumn{5}{c}{} \\
\hline \multicolumn{5}{l}{} \\
\hline P-value & Fertilizer & Harvesting age & Interaction \\
\hline
\end{tabular}

Means with different superscripts in a column and rows are significantly different from each other at $\mathrm{p}<0.05 ; \mathrm{FL}=$ fertilizer level; $\mathrm{FL} 1=$ control; FL2 $=12,000 \mathrm{~kg} / \mathrm{ha}$ compost; FL3=100kg U/ha; FL4=a mixture of $50 \mathrm{~kg}$ Urea * 6,000 kg compost/ha; HA= harvesting Age; HA1= 90 days after planting; $\mathrm{HA} 2=120$ days after planting; $\mathrm{HA} 3=150$ days after planting; $\mathrm{CV}=$ coefficient of variation; SEM = standard error of mean.

\subsubsection{Crude Protein Yield}

The effect of fertilizer, harvesting age and their interaction 
on crude protein yield (CPY) is indicated in Table 7. Crude protein yield was significantly affected by fertilizer, harvesting age and their interaction. Significantly higher (0.90t/ha) CPY was recorded at FL4HA3 followed by FL3HA3 (0.77 t/ha) and the least CPY was recorded at FL1 in all harvesting ages.

CPY was significantly affected $(\mathrm{P}<0.001)$ by harvesting age, in which CPY increased from 0.17 at 90 days of age to 0.61 at 150 days of age (Table 7). This shows that CPY increased as harvesting age delayed, the reason may be due to the highest DMY as harvesting age increased. This result is in line with the findings of Taye et al. (2007) who reported increasing trend in CPY with extended days of harvesting in case of Napier grass CPY was also significantly affected $(p<0.001)$ by fertilizer with the highest yield recorded at the fertilizer application of $50 \mathrm{~kg} \mathrm{U} \mathrm{X} \mathrm{6,000} \mathrm{compost/ha} \mathrm{(0.49),}$ while the least recorded at FL1 (control) (0.19), with the reason might be due to the low DMY obtained at this treatment.

Table 7. Crude protein yield tone/ha as affected by fertilization and harvesting age.

\begin{tabular}{lllll}
\hline $\begin{array}{l}\text { Fertilizer types } \\
\text { and levels }\end{array}$ & Harvesting age & & HA3 & Mean \\
\cline { 2 - 5 } & HA1 & HA2 & $0.26^{\mathrm{efg}}$ & $0.19^{\mathrm{y}}$ \\
FL1 & $0.11^{\mathrm{h}}$ & $0.19^{\mathrm{gh}}$ & $0.52^{\mathrm{c}}$ & $0.33^{\mathrm{x}}$ \\
FL2 & $0.16^{\mathrm{gh}}$ & $0.30^{\mathrm{def}}$ & $0.77^{\mathrm{b}}$ & $0.45^{\mathrm{w}}$ \\
FL3 & $0.22^{\mathrm{g}}$ & $0.35^{\mathrm{de}}$ & $0.90^{\mathrm{a}}$ & $0.49^{\mathrm{w}}$ \\
FL4 & $0.18^{\mathrm{gh}}$ & $0.37^{\mathrm{d}}$ & $0.61^{\mathrm{x}}$ & 0.36 \\
Mean & $0.17^{\mathrm{z}}$ & $0.30^{\mathrm{y}}$ & & \\
CV & 14.38 & & & \\
SE & 0.05 & Harvesting age & $<0.001$ & \\
P-value & Fertilizer & $<0.001$ & & \\
\hline
\end{tabular}

Means with different superscripts in a column and rows are significantly different from each other at $\mathrm{p}<0.05 ; \mathrm{FL}=$ fertilizer level; FL1=control; FL2=12,000 $\mathrm{kg} / \mathrm{ha}$ compost; FL3=100kg U/ha; FL4=a mixture of $50 \mathrm{~kg}$ Urea $* 6,000 \mathrm{~kg}$ compost $/ \mathrm{ha} ; \mathrm{HA}=$ harvesting Age; HA1= 90 days after planting; HA2=120 days after planting; $\mathrm{HA} 3=150$ days after planting; $\mathrm{CV}=$ coefficient of variation; $\mathrm{SEM}=$ standard error of mean.

\subsubsection{Economic Analysis}

Economic analysis (Table 8) indicated that application of $50 \mathrm{~kg}$ U X 6,000 compost/ha fertilizer gave the highest benefit-cost ratio (2.46) with a net benefit of 32,622.08 Birr, followed by the application of $100 \mathrm{~kg} \mathrm{U} / \mathrm{ha}$ with a net benefit of 22,211.43 Birr.

Table 8. Economic analysis on per hectare basis of dried Desho grass as affected by fertilization in ETB.

\begin{tabular}{llllll}
\hline $\begin{array}{l}\text { Fertilizer types and } \\
\text { levels }\end{array}$ & Total fixed cost & Total variable cost & Total expenditure & Gross income & Net income \\
\hline FL1 & $21,571.65$ & - & $21,571.65$ & $23,170.26$ \\
RL2 & $21,571.65$ & 200.00 & $21,771.65$ & $35,131.1$ & $1,598.62$ \\
FL3 & $21,571.65$ & $1,275.00$ & $22,846.65$ & $45,058.1$ & 1.61 \\
FL4 & $21,571.65$ & 737.50 & $22,309.15$ & $54,931.2$ & $32,211.43$ \\
\hline
\end{tabular}

$\mathrm{FL}=$ fertilizer level; FL1=control; FL2=12,000 kg/ha compost; FL3=100kg U/ha; FL4=a mixture of $50 \mathrm{~kg}$ Urea * 6,000 kg compost/ha; ETB = Ethiopian Birr.

While FL1 (control) gave the least net benefit $(1,598.616$ Birr). Therefore; applying of a mixture of organic and inorganic fertilizer was found to be more economically feasible compared to the rest of fertilizer treatments used.

\section{Discussion}

The highest mean plant height value recorded as the age of plants increased might be due to the well-established root development and nutrient uptake ability of the grasses which in turn could be manifested by the increment of plant height. Highest plant height value $(171.13 \mathrm{~cm})$ were measured at harvesting age of 120 days, followed by harvesting age of 90 days $(110.9 \mathrm{~cm})$ in case of Banna grass (21). Plant height was relatively lower at early stages of growth, but after 60 days of harvesting, enhanced growth was observed. Plant height increased progressively as cutting interval increased in case of Napier grass [22]. Leaf length also increased with increasing age. Greater leaf length was recorded for later harvesting ages (150 days) than for the earlier periods of 90 and 120 days in case of Desho grass (23).

The declining of leaf to stem ratio with the advancement of age might be due to the loss of leaves especially from the bottom part of the plants and the accumulation of more structural materials on the stems which was assumed to be the causes for lower leaf to stem ratio. The current result is in agreement with [23] who found higher leaf to stem ratio of Desho grass at early harvesting time (90 and 120 days) compared to the later date (150 days). [22] also reported a sharp decline in the value of leaf to stem ratio as the cutting intervals increased.

The application of a mixture of $50 \mathrm{~kg} \mathrm{U} / \mathrm{ha} \times 6,000$ compost/ha showed significant interaction effect on number of tillers per plant, number of leaves/plants, number of leaves/tiller and dry matter yield increased with increasing harvesting age. This may be due to the nature of urea fertilizer which is easily soluble and available to the plants within short period of time compared to compost, which took 
relatively long time to be incorporated with the soil before being available to plants. NPK fertilizers are more efficient than the organic manures in supplying $\mathrm{N}, \mathrm{P}$ and $\mathrm{K}$ in the short run, while the compost had an advantage in supplying macro and micro nutrient elements not found in NPK fertilizer [24].

The highest leaf length and widest leaf area recorded in the current study when fertilizer is applied as compared to control one may be due to the presence of essential nutrients provided by the fertilizer for the growth of leaves of plats. The increase or decrease in leaf area per plant in different treatments may be due to the availability and flow of nutrients from inorganic and organic sources of fertilizers might be due to the less or a greater number of leaves per plant [25]. The maximum leaf area was $2407.47 \mathrm{~cm}^{-2}$ with maximum nitrogen rate $\left(150 \mathrm{~kg} \mathrm{ha}^{-1}\right)$ and minimum rate $1780.39 \mathrm{~cm}^{-2}$ under the control condition in case of maize fodder [26].

Due to the provision of essential nutrients for the growth of plants height by the fertilizer higher plant height was observed for fertilized plot over the control group. Maximum plant height value $(146.3 \mathrm{~cm})$ in $\mathrm{T} 2\left(\mathrm{~N}: \mathrm{P}_{2} \mathrm{O}_{5}\right.$ 150: $\left.60 \mathrm{~kg} \mathrm{ha}^{-1}\right)$ followed by T5 $\left(\mathrm{N}: \mathrm{P}_{2} \mathrm{O}_{5}\right.$ 112: 45+ Poultry manure $750 \mathrm{~kg}$ ha $\left.{ }^{1}\right)$ and $\mathrm{T} 6\left(\mathrm{~N}: \mathrm{P}_{2} \mathrm{O}_{5}\right.$ 112: 45+ Farm yard manure $\left.1000 \mathrm{~kg} \mathrm{ha}^{-1}\right)$ with values 141.7 and $140 \mathrm{~cm}$ plant height, respectively in case of oat. On the other hand, the control treatment T1 (no fertilizer), showed minimum plant height of $116.6 \mathrm{~cm}$ (25).

The lowest leaf to stem ratio with urea fertilizer alone and a mixture with organic fertilizer might be due to the facilitation of the growth and development of the grasses. As the growth of the grass facilitated, the portion of stem becomes higher than leaf. Higher values of blade/ stem ratio were observed in plots under lower nitrogen doses, or even not fertilized plots in case of Tanzania grasses. The leaf blade/stem ratio was affected by nitrogen doses $(\mathrm{P}<0.05)$ (27).

A mixture of organic and inorganic fertilizer provided highest tiller number, leave number/plant; leave number/tiller and DMY with the reason that such fertilizer mixtures might have highest soil fertility improvement capacity compared to the rest of fertilizer types and levels used. The current finding is in line with [24] who reported mixing of Compost: inorganic fertilizer at a proportion of 3: 1 showed significantly $(\mathrm{P}<0.05)$ higher number of tillers $(50 /$ plant, $47 /$ plant) compared to using inorganic fertilizer alone. compost: inorganic fertilizer (1: 3), compost: inorganic fertilizer (1: 1), compost alone and control treatments. Researcher [28] also observed increasing trend in the number of tillers with increasing rate of compost application.

The increment of DM\% with the advancement of age might be due to the decline of moisture content of the grass as age advanced. The current finding is supported by [23], who found that Desho grass harvested at 150 days after planting produced a significantly higher DM content compared with grass harvested at 90 and 120 days. On the other hand, the declination of $\mathrm{CP} \%$ as harvesting age advanced might be due to the lignification. As the age increased, the grass becomes lignified causing decline in CP content. The present result is supported by other researchers, a trend of increase harvesting days $(60>90>120 \mathrm{~d}$ days $)$ [29]. CP concentration of Napier hybrid grass leaves declined dramatically with increase in cutting interval from $28.2 \%$ at 40 days to $8.8 \%$ at 80 days. Similarly, $\mathrm{CP}$ concentration in whole plants declined from 40 to 80 days [22].

The increment of NDF, ADF and ADL content as age increased might be due to the development of the structural component/cell wall constituents of the grass as age increase. The present result is supported by other researchers, [30] reported that neutral detergent fiber (NDF) and acid detergent fiber $(\mathrm{ADF})$ of Desho grass increased significantly $(\mathrm{P}<0.05)$ as harvesting time delayed. The finding of [23] also suggested that the NDF and ADF content of Desho grass was highest $(77.68 \%, 45.06 \%)$ from late harvesting (150 days after planting) while it was comparatively lower for earlier harvesting periods $(72.78 \%$, and $40.27 \%)$ at 90 days, respectively. Gradual increment of lignin levels were observed as plants matured in case of Napier grass $(31,29)$. Increasing trend in ADL content was observed as the cutting days advanced [32]. This showed that ash decreased as harvesting age increased. The decrease in ash content with long harvesting interval is probably a normal phenomenon of maturity and may have been caused partly by the dilution effect of higher yields in the presence of a constant amount of available minerals in the soil [33]. Ash reduction from 71.4 at 60 days of age to 55.0 at 120 days of age in case of Napier grass [29].

The highest CP content of grasses under $100 \mathrm{~kg}$ urea fertilized plots compared to the rest might be due to the continuous vegetative growth and new tiller emergence of plants which allowed them to be succulent and fresh. On the other hand, the development of plants on the non-fertilized plots was observed to be very slow and becomes lignified (low in CP content). Maximum crude protein (10.76\%) from the application of inorganic fertilizer $\left(\mathrm{N}: \mathrm{P}_{2} \mathrm{O}_{5}\right.$ 150: $60 \mathrm{~kg} \mathrm{ha}^{-}$ ${ }^{1}$ ) followed by combination of inorganic and organic sources of fertilizer $\mathrm{N}: \mathrm{P}_{2} \mathrm{O}_{5}, 112: 45+$ Poultry manure $750 \mathrm{~kg} \mathrm{ha}^{-1}$ and $\mathrm{N}: \mathrm{P}_{2} \mathrm{O}_{5}$ 112: 45+ Farm yard manure $1000 \mathrm{~kg} \mathrm{ha}^{-1}$, respectively (25). Increased $\mathrm{CP}$ content as the level of urea fertilizer increased in the case of Cenchrus ciliaris [37] and Panicum maximum and Bermuda grass [34].

The highest NDF, ADF and ADL content of unfertilized plot compared to the fertilized groups might be due to the reason that urea fertilizer and its mixture with organic fertilizer improved the plant growth and raise new leaves and shoots, which could minimize the NDF content. But there is no renewal of leaves and tillers in the non-fertilized treatments as a result of matured tissue plant and accumulate more NDF. According to Freitas et al (2012) the lowest NDF content of the leaf blade (69.3\%) estimated for the $320-\mathrm{kg} / \mathrm{ha}$ $\mathrm{N}$ dose, which is equivalent to an $8 \%$ reduction in relation to the absence of $\mathrm{N}$ fertilization in case of Tanzania grass. The $\mathrm{N}$ application in the current study resulted in higher leaf appearance rate, a situation in which the synthesis of shorter leaf blades on tropical grasses is common [35]. These shorter 
leaf blades need lower proportion of structural tissues for their support and/or leaf architecture, which could explain their lower NDF contents [35]. ADF content of forages decreased non-significantly due to increased doses of Nitrogen fertilizer [36]. ADL content of Panicum maximum and Cenchrus ciliaris decreased with increasing the level of urea fertilizer [37]. Researcher [38] noted decreased ash content as a result of an increase in the level of urea application

\section{Conclusion and Recommendation}

The current study revealed that the agronomic performance and chemical composition of Desho grass can be improved through the addition of different fertilizer types and levels. In this regard, the application of a mixture of 50 $\mathrm{kg}$ urea $(\mathrm{U}) / \mathrm{ha}$ and $6,000 \mathrm{~kg}$ compost/ha was found to be the most appropriate level for better Desho grass production as it provides the highest dry matter yield compared to the rest of fertilizer levels and types. In addition, this fertilizer level was also found to be economically feasible as it provides high Benefit Cost Ratio (2.46) compared to the other fertilizer groups. Therefore; based on the current findings the following recommendations are drawn.

1. A mixture of $50 \mathrm{~kg}$ urea $(\mathrm{U}) / \mathrm{ha}$ and $6,000 \mathrm{~kg}$ compost/ha fertilizer application provided the highest yield. Therefore, farmers are advised to apply a mixture of organic and inorganic fertilizer to get better yield.

2. Further research is needed in different organic-inorganic fertilizer mixture in different agro-ecological zones udder rain feed and irrigation conditions.

\section{References}

[1] CSA (Central Statistical Agency). 2018. Agricultural sample survey. Report on livestock and livestock characteristics (private peasant holdings). Statistical bulletin 587.

[2] Sintayehu, G., Samuel, A., Derek, B and Ayele, S. 2010. Diagnostic study of live cattle and beef production and marketing. Constraints and opportunities for enhancing the system. The report commissioned by the Bill \& Melinda Gates Foundation at the request of the Government of Ethiopia.

[3] ATA (Agricultural Transformation Agency). 2012. Livestock value chain programs. Retrieved from Http./www.ata.gov.et/programs/value chain programs/livestock/.

[4] Tilahun, A., Solomon, $\mathrm{M}$ and Roothaert, R. 2005. Intensification of livestock feed production in Ethiopian highlands: Potential and experiences of the African Highlands Initiative. Presented at the 19th EVA Annual Conference, 8 June 2005. EVA, Addis Ababa, Ethiopia. Retrieved from http://hdl.handle.net/10568/ 76954.

[5] Alemayehu Mengistu. 2006. Pasture and Forage Resource profiles of Ethiopia. Ethiopia/FAO. Addis Ababa, Ethiopia. pp 36.

[6] Shapiro, I., Gebru, G., Desta, S., Negassa, A., Nigussie, K., Aboset, G and Mechal, H. 2015. Ethiopia livestock master plan. ILRI Project Report. International Livestock Research Institute (ILRI), Nairobi, Kenya.

[7] Bimrew, A. 2016. Evaluation of the agronomic, utilization, nutritive and feeding value of desho grass (Pennisetum pedicellatum). $\mathrm{PhD}$ Dissertation. Jimma University, Ethiopia.

[8] Welle, S., Chantawarangul, K., Nontananandh, S and Jantawat, S. 2006. Effectiveness of grass strips as barriers against runoff and soil loss in Jijiga area, northern part of Somalia region, Ethiopia. Kasetsart Journal: Natural Science. Volume 40. pp 549-558.

[9] Smith, G. 2010. Ethiopia: local solutions to a global problem. Retrieved from http://www.newag.info/en/focus/focusItem.php?a=1784.

[10] Danano, D. 2007. Improved grazing land managementEthiopia. In H. Liniger, \& W. Critchley (Eds,), Where the land is greener (pp. 313-316). Bern, Switzerland: WOCAT.

[11] IPMS Ethiopia. 2010. Improved productivity \& market success of Ethiopian farmers. Retrieved from http://www.ipms ethiopia.org/content/files/Documents/workshopsMeetings/Agri-

business_Development_Process/Report\%20on\%20IPMSCIAT\%20Agri-business $\% 20$ Development $\% 20$ Process.pdf. pp $1-27$.

[12] FAO (Food and Agriculture Organization). 2010. Food and Agriculture Organization of the United Nations. Rome, Italy. Tropicales. Volume 5: pp 77-84. DOI: 10.17138/TGFT (5) 7784.

[13] Bimrew, A., Solomon, D., Taye, T., Firew, T., Jane, W and Barbara, R. 2016. Determinants of the utilization of desho grass (Pennisetum pedicellatum) by farmers in Ethiopia. Tropical Grasslands-Forrajes Tropicales. Volume 4, Article \#2. pp 112-121.

[14] Ecocrop. 2010. Ecocrop database. FAO.

[15] Trivedi, B. K. 2002. Grasses and Legumes for Tropical Pastures. Indian Grassland and Fodder Research Institute, Jhansi- 284 003, India.

[16] Skerman, P. J and Riveros, F. 1990. Tropical grasses. FAO Plant Production and Protection Series No. 23, FAO, Rome. http://books.google.com/books?id=tCydcW6MK60C

[17] Bereket, D., Worku, B., Tewodros, T and Tesfaye, A. 2016. Best fit practice manual for Desho grass (pennisetum pedicellatum) production and management in SNNPRS, Ethiopia.

[18] AOAC (Association of Analytical Chemists). 1990. Official methods of analysis $15^{\text {th }}$ ed. AOAC Inc. Arlington, Virginia, USA. pp 1298.

[19] Van Soest, P. J., Roberston, J. B and Lews, B. A. 1991. Methods for dietary fiber, neutral detergent fiber and nonstarch polysaccharides in relation to animal nutrition. Journal of Dairy Science. Volume 74. pp 3583-3597.

[20] SAS (9.2 version). 2007. SAS Users' guide, Statistical Analysis System (SAS) Institute, Inc, Cary, NC.

[21] Berihun, M. 2005. Effect of planting patterns and harvesting Days on yield and quality of bana grass [pennisetum purpureum (1.) X pennisetum americanum (1.)]. M. sc. Thesis. Alamaya university, Ethiopia. 
[22] Wangchuk, K., Rai, K., Nirola, H., Thukten., Dendup, C and Mongar, D. 2015. Forage growth, yield and quality responses of Napier hybrid grass cultivars to three cutting intervals in the Himalayan foothills. Tropical Grasslands - Forrajes Tropicales. Volume 3. pp 142-150.

[23] Bimrew, A., Solomon, D., Taye, T., Firew, T., Aynalem, H and Jane, W. 2017. Effects of altitude and harvesting dates on morphological characteristics, yield and nutritive value of desho grass (Pennisetum pedicellatum Trin.) in Ethiopia. Agriculture and Natural Resources. Volume 51. pp 148-153.

[24] Priyadarshani, N. D. A., Amarasinghe, M. K. T. K., Subasinghe, S., Palihakkara, I. R and Kumarasinghe, H. K. M. S. 2013. Effect of organic and inorganic fertilizers on biomass production, oil yield and quality of vetiver (vetiveria zizanioides 1.). The Journal of Agricultural Sciences. volume 8, Number \#1.

[25] Ahmad, A. H., Wahid. A., Khalid. F., Fiaz. N., Zamir. M. S. I. 2011. Impact of organic and inorganic sources of nitrogen and phosphorus fertilizers on Growth, yield and quality of forage oat (avena sativa 1.). Volume 44, Article \#3. pp 147. DOI: 10.2478/v10298-012-0040-7.

[26] Aslam, M., Iqbal. A., Ibni Zamir. M. S., Mubeen. M and Amin M. 2011. Effect of different nitrogen levels and seed rates on yield and quality of maize fodder. Crop Environ. Volume 2. pp $47-51$.

[27] Freitas, P. P., da Fonseca, D. M., Braz, T. G. S., Martuscello Manoe, J. A and Santos, E. R. 2012. Forage yield and nutritive value of Tanzania grass under nitrogen supplies and plant densities. Revista Brasileira de Zootecnia. Volume 41, Article \#4. pp 864-872.

[28] Hammam, K. H., Monem, A. B. D. E. L and Hassan, E. A. 2014. Effect of organic and bio-fertilizers on vetiver plant vetiveria zizanioides, L, Nash. Egypt Journal of Agricultural Research. Volume 92, Article \#2.

[29] Ansah, T., Osafo, E. L. K and Hansen H. 2010. Herbage yield and chemical composition of four varieties of Napier (Pennisetum purpureum) grass harvested at three different days after planting. Agric. Biol. J. N. Am., 1 (5): 923-929. DOI: 10.5251/abjna.2010.1.5.923.929.

[30] Genet, T., Bimrew, A and Yeshambel, M. 2017. Effects of Harvesting Age and Spacing on Plant Characteristics, Chemical Composition and Yield of Desho Grass (Pennisetum Pedicellatum Trin.) in the Highlands of Ethiopia. Tropical Grasslands-Forrajes.
[31] Jagadeesh, C. H., Ramana Reddy, Y., Nagalakshmi, D., Mahender, M., Nalini Kumari, N., Sridhar, K and Suneetha Devi, K. B. 2017. Effect of stage of harvest on the yield, chemical composition, in vitro and in sacco digestibility of hybrid napier (Penniserum purpureum) variety APB N1. Indian Journal of Animal Research. Volume 51, Article \#1. pp 116-120.

[32] Taye, B., Solomon, M and Prasad, N. K. 2007. Effects of cutting dates on nutritive value of Napier (Pennisetum purpureum) grass planted sole and in association with Desmodium (Desmodium intortum) or Lablab (Lablab purpureus). Livestock Research for Rural Development. 19 (1). www.lrrd.org/lrrd19/1/bayb19011.htm.

[33] Ullah, M. A., Anwar, M and Rana, A. S. 2010. Effect of nitrogen fertilization and harvesting intervals on the yield and forage quality of elephant grass (pennisetum purpureum) under mesic climate of pothowar plateau. Pak. J. Agri. Sci., 47 (3), 231-234.

[34] Kering, K. M., Guretzky, J., Funderburg, E and Mosali, E. 2011. Effect of Nitrogen Fertilizer Rate and Harvest Season on Forage Yield, Quality, and Macronutrient Concentrations in Midland Bermuda grass. Agronomy and Horticulture Faculty Publications. 555.

[35] Braz, T. G. S., Fonseca, D. M., Freitas, F. P. 2011. Morphogenesis of Tanzania guinea grass under nitrogen doses and plant densities. Revista Brasileira de Zootecnia. 40 (7), $1420-1427$.

[36] Hazary, H., Bilkis, T., Khandaker, H., Akbar, A and Khaleduzzaman, M. 2015. Effect of Nitrogen and Phosphorus Fertilizer on Yield and Nutritional Quality of Jumbo Grass (Sorghum Grass $\times$ Sudan Grass). Adv. Anim. Vet. Sci. 3 (8): 444-450. http://dx.doi.org/10.14737/journal.aavs/2015/3.8.444.450.

[37] Abdi, H. 2014. Effect of nitrogen fertilizer application on agronomic traits, biomass yield and nutritive value of cenchrus ciliaris and panicum maximum grown under irrigation at Gode, Somali region. M. sc. Thesis. Haramaya University, Ethiopia.

[38] Tessema, Z., Baars, R. M. T and Alemu. 2002. Effect of plant height at cutting, source and level of fertilizer on yield and nutritional quality of Napier grass (Pennisetum purpureum Schumach.). African Journal of Range and Forage Science. 19, 123-128. http://dx.doi.org/10.2989/10220110209485783. 